\title{
IMPLEMENTATION OF INCLUSIVE EDUCATION: TEACHERS' PERSPECTIVES
}

\author{
Farida Kurniawati
}

Universitas Indonesia

\begin{abstract}
Teachers play critical and crucial roles in the successful implementation of inclusive education. The aim of the study was to examine the attitudes of teachers towards the inclusion of students with special educational needs (SEN) in regular education classrooms and how their attitudes relate to their teaching strategies in the classroom. In this study, teachers from secondary schools in Jakarta, Indonesia, were invited to participate. They completed questionnaires on attitudes to inclusion and teaching strategies. The results have revealed that teachers held positive attitudes towards the inclusion of SEN students on the three components of attitudes. They preferred to use cognitive strategies compare to individual and varied strategies. Behavioral component of attitudes significantly related to all strategies of teaching strategy. Additionally, the usage of teaching strategies were significantly depended on teachers' teaching experience and training in special education.
\end{abstract}

Keywords: inclusive education, attitudes, teaching strategies, teacher, SEN

\section{BACKGROUND OF STUDY}

Theinclusion of children with Special Educational Needs (SEN) in regular schools is a fulfillment form of the right to education for all ("Indonesia: National Report”, 2009). Education that allows children with SEN to learn alongside their peers at neighborhood schools and get necessary support is known as inclusive education. While the terminology of SEN refers to theneeds of the 'classic' population of students with communication disorders, motor skillsdisorders, sensory disorders, learning disorders, mental retardation, behavioural disorders, and students with a chronic disease (American Psychiatric Association, 2000).

Inclusive education requires a system, which referred to schools, to be adapted and modified to meet the diversity and differences of students' learning needs (Mittler, 2000). Considering that inclusive education held in regular school settings, it can be said that the successful implementation of this education is very dependent on teachers(Avramidis\& Norwich, 2002; Forlin, 2001). Whereas most teachers in regular schools do not have trainings on special education and their experiences in teaching students with SEN are also very limited (Kurniawati, De Boer, Minnaert, Mangunsong, 2016). In order to perform teachers' functions effectively, in terms of providing support and modifications for students, teachers must be adequately prepared.

Many studies have found that the attitude of teachers is a prerequisites factor successful implementation of inclusive education (Cook, 2002; Forlin, Loreman, Sharma, \& Earle, 2007; Hastings \&Oakford, 2003; Pivik, McComas, \& La Flanne, 2002). Attitude is defined as a learned and stable disposition to respond favorably or unfavorably to an object, person, institution, or event in consistent way (Corsini\&Auerbach, 1998). According to the threecomponent theory (Eagly \& Chaiken, 1993; Triandis, 1971), attitudes consist of three components: cognitive, affective, and behavioral. Previous studies showed that the more knowledge held by teachers about the SEN students, will make them more receptive and confident in dealing with such students (see Shippen et al., 2005).It was also found that positive attitudes of teachers related to their willingness to include SEN students in the classroom.

Corresponding Author Email: fafadana@gmail.com; farida1@ui.ac.id 
(e.g. Sharma, Forlin, \&Loreman, 2008). These findings emphasize the importance of helping teachers to have a positive attitude for supporting students with SEN.

In addition to attitudes, teaching strategies are also considered to play an important role for the successful implementation of inclusive education (Florian, 2009; Forlin, 2011). In the context of inclusive education, teaching strategy is defined as the process of choosing and applying methods of teachings after previously carried out assessments on students with SEN (Glaser, 1977 in Scott, Vitale, \&Masten, 1998). This might include modifications made by teachers to learning materials, assignments, examination procedures, assessment criteria, the number of group members, as well as techniques to provide feedback. It was argued that the teaching strategies are required in order to support SEN participation both in social (Maheady, Mallette, \& Harper, 2006)and academicactivities (McLeskey\& Waldron, 2002) in classrooms.

Inclusive education was formally started in Indonesia since early 2000s. Inclusive education principles contained in Indonesia's Constitution and National Education Law, No. 20/2003, and National Ministerial Decree No. 70 on Inclusive Education Services. Research on teachers' attitude towards inclusive education in Indonesia found that primary school teachershold positive attitudes towards SEN students (Kurniawati, Minnaert, Mangunsong, Ahmed, 2012), but they lack the ability to educate SEN students ("Indonesia: National Report," 2009).

As stated above, teachers' attitudes and their teaching strategies are predictors of the success of inclusive education implementation in other countries (FolsomMeek \& Rizzo, 2002; Hastings \&Oakford, 2003; Pivik, McComas, \& La Flanne, 2002), less is known, however, about attitudes of teachers in Indonesia, particulary in secondary school settings. There is also no empirical evidence yet on how teachers' attitudes relate to teachers' teaching strategies. This study therefore was set up to:

\section{Measure teachers' attitudes towards inclusive education, \\ 2. Measure teachers' teaching strategies, and}

\section{Examine relationships between teachers' attitudes and their teaching strategies.}

\section{METHODS}

\section{Participants and setting}

The study took place in several secondary schools in Jakarta, capital city of Indonesia. Respondents were teachers who taught either in grade 1,2 , or 3 . They were chosen according to convenience and purposive sampling (Boeije, 2010).

\section{Measures}

Multidimensional Attitudes toward Inclusive Educational Scale(MATIES) (Mahat, 2008) was used to measure teachers' attitudes towards inclusive education. MATIES consists of three components of attitudes, namely cognitive, affective, and behavioral.Respondents were asked to express their agreement with each component of the instrument on a 6 - point Likert scale, ranging from 'strongly disagree' (1) to 'strongly agree'(6). The higher score obtained in each component, means the more positive of teachers' attitudestowards inclusive education.Bender Classroom Structure Questionnaire(BCSQ) (Bender, 1995) was used for teaching strategy measures in the inclusive education setting. The measuring instrument has cognitive, individual and varied strategies. Teachers' usage of each indicated teaching strategy was expressed on the four-point Likert scale ranging from 'very rare' (1) to 'almost always' (4). To adapt with the Indonesian context, both the instruments undergo a process of adaptation that consist of translation, expert judgment, back-translation and readability test.

\section{RESULTS}

\section{Respondents'Characteristics}

Most of the respondents were women, aged over 50 years and had experiences in teaching between 21 30 years.

\section{Teachers' Attitudes towards Inclusive Education}

In all three components of attitudes, teachers tend to be positive towards inclusive education, for cognitive 
$(M=24.77, S D=5.180)$, affective $(M=26.04, S D=$ 4.302), and behavioral $(M=27.96, S D=4.327)$.

\section{Teachers' Teaching Strategies}

Teachers used more cognitive strategy than individual and varied strategies in teaching children with SEN in classroom (see Table 1).

Table 1: Means and SDs on Teaching Strategies $(N=$ 259)

\begin{tabular}{l|l|l}
\hline Type of Strategy & Mean & $\begin{array}{l}\text { Standar } \\
\text { Deviation }\end{array}$ \\
\hline Cognitive & 37.23 & 5.09 \\
\hline Individual & 34.34 & 4.01 \\
\hline Varied & 114.66 & 12.55 \\
\hline
\end{tabular}

Relationship between Teachers' Attitudes towards Inclusive Education and their Teaching Strategies

Results of pearson correlation show that there is a significant relationship between teachers'attitudes toward inclusive education and their teaching strategies $(r=0.293, p=0.03)$. This means that the more positive teachers' attitude towards inclusive education, the more diverse teaching strategies used by the teachers. Further analysis on components of attitudes and teaching strategies found significant relationship between behavioral component and each component of teaching strategies, on cognitive $\operatorname{strategy}(r=0.31, p=0.05)$, individual strategy $(r=$ $0.38, p=0.01)$, and varied strategy $(r=0.37, p=$ 0.01).Different result, however, was found on the relationship between the two other components of attitudes and teaching strategies. In addition, analysis regarding predictor values of research variables found KP score of $9 \%$. This means that attitudes of teachers influenced their teaching strategies by $9 \%$, while $91 \%$ are influenced by other factors.

\section{DISCUSSION}

The aims of this study were to measure 1) teachers' attitude towards inclusive education 2) teachers' teaching strategies and 3) relationship between teachers' attitude and their teaching strategies. The results showed that teachers hold positive scores on all three components of the attitude. Deals with teaching strategies, it was found that teachers applied more cognitive strategies than other strategies. A significant relationship was found between attitudes and teaching strategies, but the relationship is relatively weak as the influence of teachers' attitudes on their teaching strategies only as much as $9 \%$.

Positive attitude of teachers towards inclusive education found in this study was also found in the teachers who taught at elementary schools in Indonesia (see Kurniawati, et al., 2012). This result does not seem surprisingly with the consideration that the teachers teaching in school that are designated to include students with SEN. In the inclusive educational setting, teachers are required to directly interact with students with SEN. This finding could be explained in relation to the theory of attitude formation (Eagly \& Chaiken, 1993) which states that attitudes are formed by direct and indirect experience.

Another result revealed that cognitive and affectivecomponents of attitude towards inclusive education have no significant relationship with all the teaching strategies. The findings might be explained from several factors. First, this may be related to teaching experiences of teachers. As much as $39 \%$ of respondents had teaching experiences from 11 to 20 years. Previous studies reveal that teachers with teaching experiences for ten years and more were more realistic of teaching barriers in inclusive settings, consequently be more reluctant of accommodating the learning need of SEN students (Forlin, 1995, in Avramidis \& Norwich, 2002).

Second, the finding could be related to the class size (Bender, 1995). The average number of students in one class is 40 children, this size makes teachers often feel overwhelmed and have no time to prepare various teaching strategies. Teachers therefore tend to use the same type of teaching strategies to all students.Third, this might be associated with teachers lacking of knowledge and teaching experiences on special education (Avramidis\&Norwich, 2010; Scott, Vitale, \&Masten, 1998). Indonesian government has actually equipped teachers with training, but it's still comparatively little training which only contains basic knowledge, not about teaching strategies (Kurniawati et al., 2016). Last, teachers inability to implement appropriate teaching strategies due to lack of school support, such as learning materials, teachers' assistant (Avramidis\&Norwich, 2010; Scott, Vitale, \&Masten, 1998). 
As researchs on teachers' attitudes and their teaching strategies on secondary schools is still scarce, this study could be considered as stepping stone for improving teachers' competence and confidence in educating SEN students. For future research, the usage of another method such as observation might provide better picture of teachers' activities in the classroom, including their teaching strategies.

\section{REFERENCES}

American Psychiatric Association. (2000). Diagnostic and statistical manual of mental disorders(DSM-IVTR) (4th ed.). Washington, DC: American Psychiatric Association.

Avramidis, E., \& Norwich, B. (2002). Teachers' attitudes towards integration/inclusion: A review of the literature. European Journal of Special Needs Education, 17(2), 129-147.

Avramidis, E., Bayliss, P., \& Burden, R. (2000). Student teachers' attitudes towards the inclusion of children with special educational needs in the ordinary school. Teaching and Teacher Education, 16(3), 277-293.

Avramidis, E., Bayliss, P., \& Burden, R. (2002). Inclusion in action: An in-depth case study of an effective inclusive secondary school in the south-west of England. International Journal of Inclusive Education, 6(2), 143-163.

Bender, W. N., Vail, C. O., \& Scott, K. (1995). Teachers' attitudes toward increased mainstreaming: Implementing effective instruction for students with learning disabilities. Journal of Learning Disabilities, 28(2), 87-94.

Boeije, H. R. (2010). Analysis in qualitative research.London, UK: Sage.

Cook, B. G. (2002). Inclusive attitudes, strengths, and weaknesses of pre-service general educators enrolled in a curriculum infusion teacher preparation program. Teacher Education and Special Education, 25(3), 262-277.

Corsini, R. J., \& Auerbach, A. J. (Eds.). (1998). Concise encyclopedia of psychology (2nd ed.). NewYork: John Wiley \& Sons.

Eagly, A.H., \& Chaiken, S. (1993). The nature of attitudes. InA.H. Eagly \& S.Chaiken (Eds.),The Psychology of attitudes(1sted., pp. 1-21). Fort Worth, TX: Harcourt Brace, Jovanovich.

Florian, L. (2009). Towards inclusive pedagogy. In P. Hick, R. Kershner, \& P. Farrell (Eds.), Psychology for inclusive education: New directions in theory and practice (pp. 38-51).London: Routledge/Falmer.

Folsom-Meek, S. L., \& Rizzo, T. L. (2002). Validating the physical educators' attitude toward teaching individuals with disabilities III (PEATID III) survey for future professionals. Adapted Physical Activity Quarterly, 19(2), 141-154.

Forlin, C. (2001). Inclusion: Identifying potential stressors for regular class teachers. Educational Research, 43(3), 235-245.

Forlin, C. (2011). Developing and implementing quality inclusive education in Hong Kong: Implications for teacher education. Journal of Research in Special Education Needs, 10(3), 41-48.

Forlin, C., Loreman, T., Sharma, U., \& Earle, C. (2009). Demographic differences in changing preservice teachers' attitudes, sentiments and concerns about inclusive education. International Journal of Inclusive Education, 13(2), 195-209.

Hastings, R. P., \& Oakford, S. (2003). Student teachers' attitudes towards the inclusion of children with special needs. Educational Psychology, 23(1), 87-94.

Indonesia: National report on the provision of inclusive quality primary and junior secondary education for children with disabilities (2009). Retrieved from http://www.Ibe.Unesco.Org.

Kurniawati, F., Minnaert, A., Mangunsong, F., \& Ahmed, W. (2012). Empirical study on primary school teachers' attitudes towards inclusive education in Jakarta, Indonesia. Procedia - Social and Behavioral Sciences, 69, 1430-1436.

Kurniawati, F., Evaluating the effect of a teacher trainingprogramme on the primary teachers' attitudes,knowledge and teaching strategies regardingspecial educational needs. EducationalPsychology, DOI: 10.1080/01443410.2016.1176125.

Mahat, M. (2008). The development of a psychometrically-sound instrument to measureteachers' multidimensional attitudes toward inclusive education. International Journal of Special Education, 23(1), 82- 92.

Maheady, L., Mallette, B., \& Harper, G. F. (2006). Four class wide peer tutoring models: Similarities, differences, and implications for research and practice. Reading and Writing Quarterly: Overcoming Learning Difficulties, 22, 65-89.

McLeskey, J., \& Waldron, N. L. (2002). Inclusion and school change: Teacher perceptions regarding curricular and instructional adaptations. Teacher Education and Special Education, 25(1), 41-54.

Mittler, P. (2000). Working towards inclusive education: Social context. London, UK: Fulton

National Education System Act (2003). Republic of Indonesia. 
Pivik, J., McComas, J., \& LaFlanne, M. (2002). Barriers and facilitators to inclusive education. Exceptional Children, 61(1), 97-107.

Scott, B.J., Vitale, M.R., \& Masten, W.G. (1998). Implementing instructional adaptations for students with disabilities in inclusive classrooms: A literature review. Remedial and Special Education, 19(2), 106119.
Sharma, U., Forlin, C., \& Loreman, T. (2008). Impact of training on pre-service teachers' attitudes and concerns about inclusive education and sentiments about persons with disabilities. Disability \& Society, 23(7), 773-785.

Triandis, H. C. (1971). Attitudes measurement and methodology. In H. C. Triandis (Ed.), Attitudes and attitude change (pp. 26-59). New York, NY: John Wiley \& Sons. 